\title{
MODELING OF EVAPORATION LOSSES IN SEWAGE SLUDGE DRYING BED
}

\author{
J. I. Obianyo ${ }^{1, *}$ and J. C. Agunwamba ${ }^{2}$ \\ 1 Department of Civil EngineEring, Michael OKPara Univ. of Agriculture, Umudike, Abia State NiGERIA. \\ 2 DePartment of Civil ENGineERING, University of NigERIA, NSUKKA, ENUGU STATE. NIGERIA.
}

Email addresses:1 jiobianyo@yahoo.com,2nwambaagu@yahoo.com

\begin{abstract}
A model for evaporation losses in sewage sludge drying bed was derived from first principles. This model $w-q_{e s}=w e^{k t}$ was developed based on the reasoning that the rate at which evaporation is taking place is directly proportional to the instantaneous quantity of water in the sludge. The aim of this work was to develop a model to assist in the design of drying beds for effective treatment of wastes derived from households' septic systems. Data generated after evaporation experiment in sewage sludge drying bed over a period of 15 days at 24 hours intervals was used for the modeling. The model was calibrated and regressed using data for days 1 to 8 by employing the Pearson's correlation coefficient, " $r$ " was found to be -0.96124 , after which verification was done and regressed using data for days 9 to 15 and $r$ was found to be 0.9969 that these fits validates the model. Materials balance show that evaporation reduces with increase in seepage losses which can be enhanced with use of conditioners and coarser sands because of their larger pore spaces. It was discovered that evaporation from the sludge follows first order kinetic in agreement with the fundamental concept. The model will help in the prediction of total water losses due to evaporation over a given period which would aid in the design of drying beds.
\end{abstract}

Keywords: modeling, evaporation losses, sewage sludge, drying bed

\section{INTRODUCTION}

The aim of this study was to develop a model to be used in the prediction of total evaporation losses in sewage sludge drying bed. Sludge dewatering is a physical unit process used to remove as much water as possible from sludge to produce a highly concentrated cake, and is dried naturally by a combination of seepage and evaporation. The rational equation for drying is dependent on time for sludge to drain (i.e. the time during which draining is the primary drying mechanism in days), and time for moisture to evaporate from the drained sludge [1]. Raw sludge is watery, containing only $2 \%$ solids. Hence, sludge drying process reduces mass and volume of the product, making its storage, transport, packaging and retail easier and also enables incineration and co-incineration of sludge, facilitate handling for downstream unit. This is achieved through thickening by gravity or air floatation [2].. Sludge, which is produced as a byproduct of all treatment processes, has considerable potential as a fertilizer and soil conditioner.
Conventional sand beds consist of a layer of coarse sand $15-25 \mathrm{~cm}$ in depth and supported on a gravel bed $(0.3-2.5 \mathrm{~cm})$ that incorporates selected tiles or perforated pipe under-drain. The drying period is 10 15 days and the moisture content of the cake is 60$70 \%$. The sludge for land application must meet riskbased pollutants limit to protect public health and the environment [3]. Drying beds are not adapted for regions with heavy rain falls and frequent flooding or where the water table is high. In any case, the ponds should be sealed to prevent infiltration of the pathogen containing percolate and a counter bund can prevent runoff to flow in. The form of the product obtained after dewatering process is hardly acceptable by several clients, including among others agriculture, forestry, as well as power industry [4]. The product requires further transformation, more advance treatment. This shall be the task of sludge drying process, understood as thermal drying process in which thermal energy is delivered to the sludge in order to evaporate water [5].The exchange of mass and heat between dried sludge and air (material and 
factor) is of essential significance for the drying process. The heat exchange is achieved through radiation, convection and conduction. Moisture mass goes from the area of higher concentration to the area of smaller concentration as a result of diffusion [4]. Three phases of drying exist in the use of thermal energy to dry sludge. The first phase of sludge drying process is preliminary drying. During this very short phase the temperature of sludge is increasing up to a certain constant value. After the preliminary drying the next phase called the essential drying begins. It is the longest phase of drying during which moisture evaporates from the surface of the sludge particles with a constant speed, not dependent on the type of sludge. The whole surface of sludge particle is covered with water which constantly evaporates and is replaced by the water from inside of the particle. The temperature of sludge during basic drying phase is constant and is the same as the temperature of surrounding water $\left(50-58^{\circ} \mathrm{C}\right)[6]$.

The time of basic drying depends on the difference between the moistness on the surface of the sludge particle and the amount of not bonded water inside the sludge particle. The last phase of sludge drying is final drying. It begins when the moistness of sludge reaches critical value, for which the temperature of sludge is beginning to increase. Water from the surface of sludge evaporates quicker than it is replaced from the inside of the particle. The speed of drying in the last phase is decreasing until balanced hydration (dependent on the drying temperature and air humidity) is achieved [7].

Nevertheless, partial drying (up to $30-40 \%$ of dry solid (DS)) and total drying (80 - 97\% of DS) is suggested as the most convenient for the drying process and the drying facility exploitation. Conventional heat-drying is, however, technically complex, requiring high investment and consuming large quantities of energy [8, 9]. Often, therefore, solar drying of sludge turns out to be a better solution especially, for small to middle-sized sewage plants [9 - 12].

Despite the increasing importance of solar drying of sludge, models to predict the drying rate are still not available except the one developed by [13]. Several researches have been carried out on sludge drying using thermo-systems and solar radiation but not particularly on the development of models for the estimation of evaporation losses in sludge drying beds, Nevertheless, and to the best of our knowledge [13] developed a model to predict evaporation losses from sewage sludge drying beds. The result is an estimate of the evaporation rate, and may be expressed as;

In which

$$
E=p\left(w_{\text {out }}-w_{\text {in }}\right) Q_{v} \equiv P \Delta w Q_{v}
$$

$w_{\text {out }}$ and $w_{\text {in }}$ are the humidity ratios of the ventilating air at outlet and inlet, $\rho$ is the density of air and $Q_{v}$ is the discharge of the ventilating fans respectively [14. Developed a general model governing both short- and long-term effects of seepage losses in sewage sludge drying bed. The model is a first order kinetic and indicate that inverse relationship exist between seepage and time, given by the expression;

$$
q_{s}=a+b e^{k_{1} t}
$$

For short-term effect, the intercept ' $a$ '=0 so that Equation (2) reduces to

$$
q_{s}=b e^{k_{1} t}
$$

Integrating Equation (3) between the limits $t=0$ and $t$ $=\mathrm{T}$, gave:

$$
q_{s}=\frac{b}{k_{1}}-\frac{b e^{k_{1} t}}{k_{1}}
$$

Where $q_{s}$ is the total seepage over a given period, $\mathrm{T}$ is the time, $\mathrm{k}_{1}$ rate constant, $\mathrm{b}$ is the slope and $\mathrm{e}$ is the base of Napieran logarithm

For long-term effect of seepage, ' $a ' \neq 0$, so that the general seepage model, Equation (2) applies and if integrated between the limits $t=0$ and $t=T$, it reduces to

$$
q_{s}=a T+b\left(\frac{e^{k_{1} t}}{k_{1}}-\frac{1}{k_{1}}\right)
$$

Where $a=$ intercept on the horizontal axis due to long-term effect of seepage. Other parameters retain their nomenclature as defined above.

Seepage from drying beds is enhanced by the use of conditioners [15]. This implies that the rate of evaporation from drying beds will reduce appreciably if a conditioner is used in drying sludge. The article [15] showed that dewater ability enhancement ratios (DER) when $\mathrm{FeCl}_{3}$ conditioner was used for drying sewage sludge were 1:1 for control experiment when no conditioner was used (i.e. $0 \mathrm{~g} \mathrm{FeCl}$ dose), 1:27.72, $1: 46.59,1: 51.72,1: 53.62$ and $1: 61.34$ for $30 \mathrm{~g}, 60 \mathrm{~g}$, $90 \mathrm{~g}, 120 \mathrm{~g}$ and $150 \mathrm{~g}$ of $\mathrm{FeCl}_{3}$ doses respectively. DER is the ratio of maximum discharge at any given coagulant dose $(\gamma)$ to the maximum discharge for control experiment $(\varepsilon)$.

Destruction of pathogenic organisms is one of the major reasons for drying sludge in sand beds [16]. It 
has been shown that pathogen die-off is not significant at high moisture contents. Experiment for the study of short- and long-term effects of drying sludge was conducted over a period of 76 days. The fate of faecal coliform die-off was monitored at various depths starting from the surface (i.e. $0 \mathrm{~mm}$ depth), $60 \mathrm{~mm}$, $120 \mathrm{~mm}, 180 \mathrm{~mm}$ and $240 \mathrm{~mm}$ respectively. Results indicate that despite the fact that solar radiation destroys pathogens, its effect is not so significant at high moisture contents. This is evident from the pathogen die-off trend whose rate was consistently increasing during the last 18 days of the experiment, a condition which started prevailing when the moisture content of sludge had decreased from 88.99 per cent to 65.48 per cent.

Also, in an experiment conducted to investigate the moisture variation associated with water input and evaporation during sewage sludge bio-drying [17] discovered that the moisture in the sewage sludge biodrying material decreased from $66-54 \%$ in response to control technology for bio-drying. They also observed that during the temperature increasing and thermophilic phases of sewage sludge bio-drying, the moisture content, water generation and water evaporation of the bulk initially increased and then decreased [17]. Forced aeration can equally enhance evaporation from drying beds because of its positive influence in increasing air velocity across sewage sludge bio-drying pile [18] in their experiment conducted to investigate the effects of forced air volume on the evaporation of water from sewage sludge bio-drying pile, observed that air velocity above the pile during aeration was $43-100 \%$ higher than when there was no aeration, and there was significantly positive correlation between air volume and water evaporation from day 1 to 15 . The order of daily means of water evaporation was thermophilic phase $>$ second temperature - increasing phase $>$ temperature - increasing phase $>$ cooling phase. Forced aeration controlled the pile temperature and improved evaporation, making it the key factor influencing water loss during the process of sewage sludge bio-drying.

\section{EXPERIMENTAL SETUP AND PROCEDURE}

Moisture content test was conducted on the sewage sludge in accordance with [19] to determine the initial water content. In this experiment, 2.0155g sludge sample was oven dried at $105^{\circ} \mathrm{C}$, and after two successive weighing of the sludge sample, moisture content was computed when the difference between the weights of the oven-dried sample did not exceed $0.1 \%$ and result showed that moisture content was $81.1 \%$. Further to that, $60.95 \mathrm{~kg}$ of sludge containing $49.37 \mathrm{~kg}$ of water based on $81.1 \%$ water content was weighed and placed inside a container; $64.05 \mathrm{~kg}$ of water was added to the sludge, making a total weight of $125 \mathrm{~kg}$ of sewage sludge the water content thus, increased from $80.1 \%$ to $90.7 \%$ to enhance flow ability. The contents were thoroughly mixed to a uniform consistency before application into the drying bed.

The drying bed is a simple sand and gravel filters on which batch loads of sludge are dewatered. Generally, the gravel layer (grain diameter of $7-15 \mathrm{~mm}$ ) of $20 \mathrm{~cm}$ thick was used, and this is followed by a final sand layer (grain diameter of $0.2-0.6 \mathrm{~mm}$ ). The dimensions of the drying bed(i.e. the model) is $100 \mathrm{~cm}$ long, $30 \mathrm{~cm}$ wide, $70 \mathrm{~cm}$ deep, the drain pipe is $50 \mathrm{~cm}$ and the length extending into the bed is perforated so that filtration can take place as shown in Figures 1 and 2 . The weight of the evaporation can is $79.0 \mathrm{~g}, 15 \mathrm{~cm}$ diameter and $20 \mathrm{~cm}$ deep. Sludge were introduced on the bed intermittently and the percolate collected at 24 hours interval for 15 days. Two hours after the final application of sludge on the bed, $1638.0 \mathrm{~g}$ of sludge was collected from the bed and placed inside the evaporation can, kept by the side of the bed and evaporation allowed to take place for 15 days also at 24hours interval and simultaneously with seepage. Moisture contents in the sand and gravel media are not constant but vary with time, so that three samples were collected from these media at four days intervals and moisture content tests conducted. Results showed that moisture contents of the sand and gravel layers are approximately $10 \%$ and $7.5 \%$ respectively

Since evaporation is directly proportional to surface area [20], evaporation from the drying bed (model) was determined by multiplying the evaporation from the evaporation can by the area ratio $A_{c} / A_{m}$, where $A_{c}$ and $A_{m}$ are the surface areas of the evaporation can and models respectively, this is a major limitation in this work because of unavailability of evaporation meter.

After the experiment, data obtained were used to calibrate and verify the model. In this research, the first eight data corresponding to days 1 to 8 were used for calibration while the remaining seven data corresponding to days 9 to 15 were used for verification by using the Pearson's coefficient of correlation. 


\section{MATHEMATICAL DERIVATIONS}

Assumption: Moisture content of the sand and gravel layers vary as seepage and evaporation take place. But for ease of modeling, their moisture contents were assumed to be constant.

Let $q_{e}$ be the evaporation from the evaporation can, $q_{e}$ $=$ evaporation from the corresponding drying bed, $q_{r t d}$ the instantaneous quantity of water retained in the sludge at any time $t$ (days).

And $w$ the initial quantity of water in sludge.

$\left(\Rightarrow w-q_{e}-q_{s}\right)$ is the quantity in $\left(m^{3}\right)$ of water retained in the sludge after time $t$ days.

$$
\begin{aligned}
\therefore & \frac{d q}{d t}=k\left(w-q_{e}-q_{s}\right) \\
& \frac{d q}{\left(w-q_{e}-q_{s}\right)}=k d t
\end{aligned}
$$

Integrating both sides of Equation (7)

$$
\text { In }\left(w-q_{e}-q_{s}\right)=k t+\operatorname{In} c
$$

Where $\mathrm{k}$ is the rate constant

$$
\left(w-q_{e}-q_{s}\right)=c e^{k t}
$$

$$
\begin{array}{r}
q_{n d}=\left(w-q_{e}-q_{s}\right) \\
\therefore q_{r t d}=\left[w-\left(q_{e}+q_{s}\right)\right]
\end{array}
$$

The general equation for evaporation from drying bed is given by the expression

$$
\left[w-\left(q_{e}+q_{s}\right)\right]=w e^{k t}
$$

Linearizing Equation (12), we have

$$
\ln \left(w-q_{e}-q_{s}\right)=\ln w+k t
$$

Regression of $\ln \left(w-q_{e}-q_{s}\right)$ on time, $t$ will enable obtain the intercept $\ln w$ and the slope $k$.

From Equation (7),

$$
q_{e}=w\left(1-e^{k t}\right)-q_{s}
$$

Where $q_{s}$ is the instantaneous evaporation from the drying bed, $W$ is the instantaneous quantity of water in the sludge; $q_{s}$ is the instantaneous seepage from the drying bed; $K$ is the rate constant; and t is the time Equation (10) is the instantaneous evaporation from the drying bed, to determine the total losses over a given period of time due to evaporation from the drying bed, we integrate Equation (10) between the limits $\mathrm{t}=0$ and $\mathrm{t}=\mathrm{T}$, thus:

At $t=0=q_{\text {es }}, w=c$

$q_{e s}$ is the sum of evaporation and seepage losses

Note that

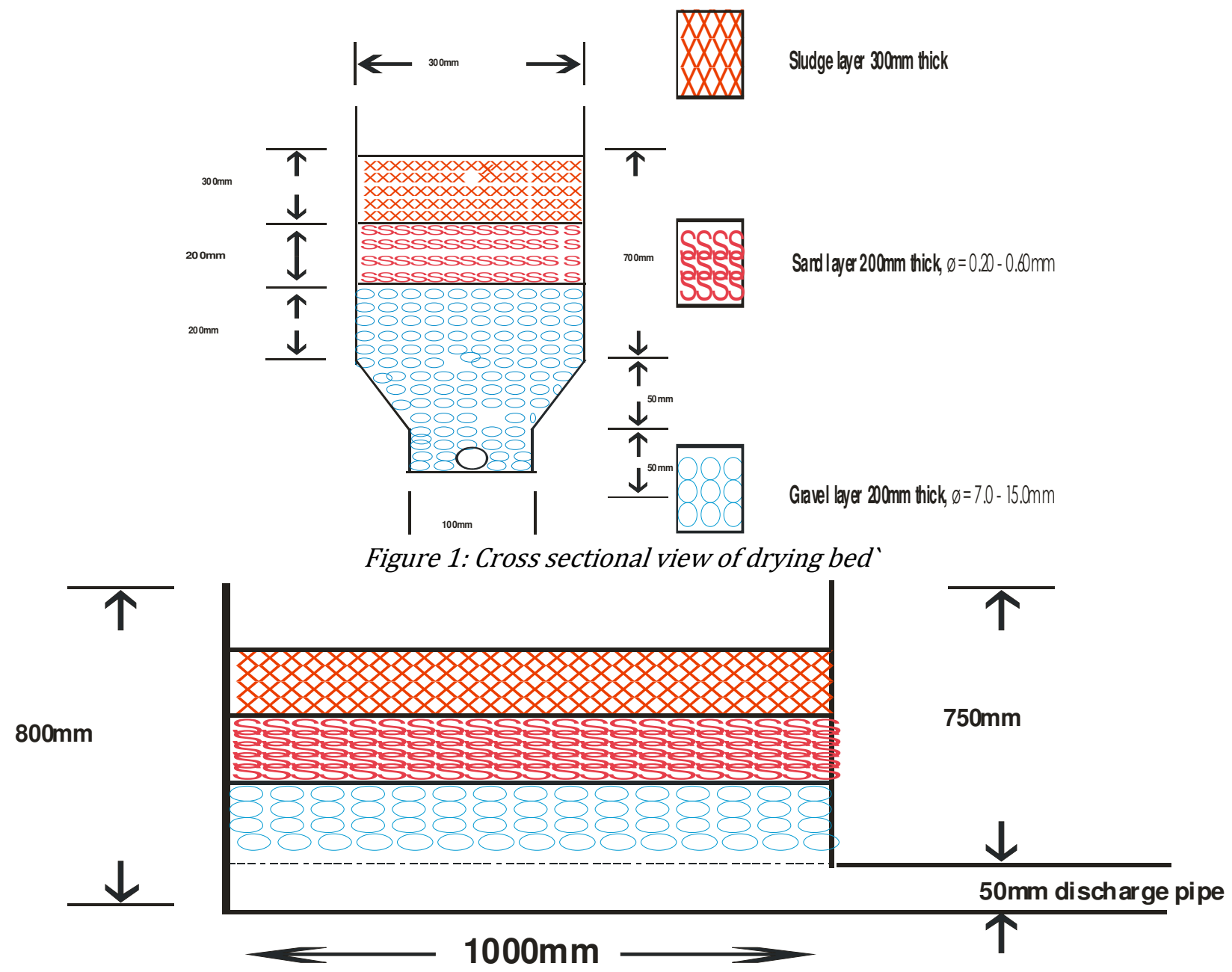

Figure 2: Longitudinal view of drying bed 


$$
\int_{t-0}^{t-T} q_{e} d t=w\left(T-\frac{e^{k T}}{k}\right)-q_{s} T-\frac{w}{k}
$$

This implies that total losses due to evaporation from the drying bed is given by the expression;

$$
q_{e} T=w\left(T-\frac{e^{k T}}{k}\right)-q_{s} T-\frac{w}{k}
$$

\section{RESULTS AND DISCUSSIONS}

Surface area of the evaporation can surface diameter, $\phi=15 \mathrm{~cm}, A_{c}=176.67 \mathrm{~cm}^{2}$

Surface area of the drying bed, dimensions $(100 \mathrm{~cm} \times 30 \mathrm{~cm}), A_{m}=3000 \mathrm{~cm}^{2}$

Area ratio, $A,=\frac{1}{16.98}$.

$\mathrm{q}_{\mathrm{c}}$ is the water loss from the evaporation can.

Table 1: Evaporation from the evaporation can, drying bed, seepage and instantaneous quantity of water retained

\begin{tabular}{|c|c|c|c|c|c|}
\hline$t(d a y s)$ & $q_{c}\left(\times 10^{-3}\right) m^{3}$ & $q_{e}\left(\times 10^{-3}\right) m^{3}$ & Seepage $q_{s}\left(\times 10^{-3}\right) m^{3}$ & $\left(q_{e}+q_{s}\right)\left(\times 10^{-3}\right) m^{3}$ & {$\left[w-\left(q_{e}+q_{s}\right)\right]\left(\times 10^{-3}\right) m^{3}$} \\
\hline 0 & 0 & 0 & - & - & - \\
\hline 1 & 159 & 2699.82 & 19641 & 22340.82 & 71230.68 \\
\hline 2 & 128 & 2173.44 & 10936 & 13109.44 & 58121.24 \\
\hline 3 & 120 & 2037.60 & 6823 & 8860.60 & 49260.64 \\
\hline 4 & 125 & 2122.50 & 4087 & 6209.50 & 43051.14 \\
\hline 5 & 80 & 1358.40 & 2779 & 4137.40 & 38913.74 \\
\hline 6 & 68 & 1154.64 & 2557 & 3711.64 & 35202.10 \\
\hline 7 & 90 & 1528.20 & 2539 & 4067.20 & 31134.90 \\
\hline 8 & 36 & 611.28 & 2312 & 2923.28 & 28211.62 \\
\hline 9 & 62 & 1052.76 & 2192 & 3244.76 & 24966.86 \\
\hline 10 & 52 & 882.96 & 2121 & 3003.96 & 21962.90 \\
\hline 11 & 51 & 865.98 & 2067 & 2932.98 & 19029.92 \\
\hline 12 & 42 & 713.16 & 2011 & 2724.16 & 16305.76 \\
\hline 13 & 38 & 645.24 & 1933 & 2578.24 & 13727.52 \\
\hline 14 & 37 & 628.26 & 1878 & 2506.26 & 11221.26 \\
\hline 15 & 7 & 118.26 & 1850 & 1968.86 & 9256.40 \\
\hline
\end{tabular}
in sludge at 24 hours intervals

Table 2: Calibration of evaporation model

\begin{tabular}{lllll}
\hline$t$ & $\ln \left(w-q_{e s}\right)$ & $t^{2}$ & \multicolumn{1}{c}{$\ln \left(w-q_{e s}\right)^{2}$} & $t . \ln \left(w-q_{e s}\right)$ \\
\hline 1 & 4.2659 & 1 & 18.1979 & 4.2659 \\
2 & 4.0625 & 4 & 16.5039 & 8.1250 \\
3 & 3.8971 & 9 & 15.1874 & 11.6913 \\
4 & 3.7624 & 16 & 14.1557 & 15.0496 \\
5 & 3.6613 & 25 & 13.4051 & 18.3065 \\
6 & 3.5610 & 36 & 12.6807 & 21.3662 \\
7 & 3.4382 & 49 & 11.8212 & 24.0674 \\
8 & 3.3397 & 64 & 11.1536 & 26.7176 \\
9 & 3.2177 & 81 & 10.3536 & 28.9593 \\
10 & 3.0892 & 100 & 9.5432 & 30.8920 \\
11 & 2.9460 & 121 & 8.6789 & 32.4060 \\
12 & 2.7918 & 144 & 7.7941 & 33.5016 \\
13 & 2.6203 & 169 & 6.8660 & 34.0639 \\
14 & 2.4177 & 196 & 5.8453 & 33.8478 \\
15 & 2.2257 & 225 & 4.9537 & 33.3855 \\
\hline
\end{tabular}

$$
\begin{gathered}
\sum t=36 \sum \ln \left(w-q_{e s}\right)=30.06 \sum t^{2}=204 \sum \ln \left(w-q_{e s}\right)^{2}=113.73 \sum t \cdot \ln \left(w-q_{e s}\right) \\
\left(w-q_{e}-q_{s}\right)=\left(w-q_{e s}\right)
\end{gathered}
$$




$$
\begin{gathered}
Y=\frac{n \sum t \cdot \operatorname{In}\left(w-q_{e s}\right)-\sum t \sum \operatorname{In}\left(w-q_{e s}\right)}{\left[n \sum t^{2}-\left(\sum t\right)^{2}\right]^{\frac{1}{2}}\left[n \sum \operatorname{In}\left(\sum w-q_{e s}\right)^{2}-\left(\sum \operatorname{In}\left(w-q_{e s}\right)\right)^{2}\right]^{\frac{1}{2}}} \\
\text { slope, } K=\frac{n \sum t \cdot \operatorname{In}\left(w-q_{e s}\right)-\sum t \sum \operatorname{In}\left(w-q_{e s}\right)}{\sum t^{2}-\left(\sum t\right)^{2}}
\end{gathered}
$$

$\ln \bar{y}=\ln w+k \bar{t}, \quad$ or $\quad \bar{y}=\overline{w-q_{e s}}$

Using Equations 17, 18 and 19 and solving, we obtain;

$$
\begin{gathered}
r=-0.96124, k=-0.1336, \ln w=4.3587 \\
w=e^{43587}=78155 \\
\therefore \operatorname{In}\left(w-q_{e s}\right)=4.3587-0.1336 t
\end{gathered}
$$

Equation (16) governs evaporation in sewage sludge drying bed.

This model was used to derive the instantaneous calculated quantities of water in the sludge as shown in the Table 2 below. This exercise is called verification and was carried out using data for days 9 to 15

Let $\mathrm{X}=\left(\mathrm{W}-\mathrm{q}_{\mathrm{es}}\right)_{\text {measure, }}$ and $\mathrm{y}=\left(\mathrm{W}-\mathrm{q}_{\mathrm{es}}\right)_{\text {calculated }}$

Table 3: Verification of evaporation model

\begin{tabular}{ccccl}
\hline$x$ & $y$ & $x^{2}$ & $y^{2}$ & \multicolumn{1}{c}{$x y$} \\
\hline 3.2177 & 3.1563 & 10.3684 & 9.9622 & 10.1633 \\
3.0892 & 3.0227 & 9.5481 & 9.1367 & 9.3401 \\
2.9460 & 2.8891 & 8.7025 & 8.3469 & 8.5228 \\
2.7918 & 2.7555 & 7.7841 & 7.5928 & 7.6878 \\
2.6203 & 2.6219 & 6.8644 & 6.8744 & 6.8694 \\
2.4177 & 2.4883 & 5.8564 & 6.1916 & 6.0217 \\
2.2257 & 2.3547 & 4.9729 & 5.5446 & 5.2510 \\
\hline
\end{tabular}

$$
\begin{gathered}
\sum x=19.32 \sum y=19.2885 \\
\sum x^{2}=54.0968 \sum y^{2}=53.6492 \sum x y=53.8561
\end{gathered}
$$$$
r=0.9969, b=0.0 .8012
$$

$$
\bar{q}_{e-c a l}=a+b \bar{q}_{e-m e s}
$$

$$
\frac{19.2885}{7}=a+0.8012\left(\frac{19.32}{7}\right)
$$

solving, $\mathrm{a}=0.5441$

$$
\Rightarrow q_{e-c a l}=0.5441+0.8012_{q-m e s}
$$

The relationship between predicted and measured evaporation is given by Equation (21).

\subsection{Material Balance}

It is important to note that quantity of water in the sludge must equal the sum of quantity of water evaporated and the quantity of water as seepage, and is given by the expression below;

$$
q_{t}=q_{e}+q_{s}+\left(q_{s w}+q_{s d}+q_{s g}\right)
$$

$q_{t}$ is the Total /initial quantity of water in the sludge $\left(\mathrm{m}^{3}\right)$

$q_{e}$ is the evaporated quantity of water $\left(\mathrm{m}^{3}\right), q_{s}$ is the quantity of water as seepage $\left(\mathrm{m}^{3}\right), q_{s w}$ is the quantity of water retained in the sewage $\left(\mathrm{m}^{3}\right), q_{s d}$ is the quantity of water in the sand layer $\left(\mathrm{m}^{3}\right)$ and $q_{s g}$ is the quantity of water in the gravel layer $\left(\mathrm{m}^{3}\right)$.

$$
\begin{aligned}
& \text { Let } q_{b}=\left(q_{s w}+q_{s d}+q_{s g}\right) \\
& q_{t}=q_{e}+q_{s}+q_{b}
\end{aligned}
$$

Where $q_{b}$ is the quantity of water in the drying bed Application of this model is based on the design criteria shown in Table 4

Table 4: Design criteria for drying bed

\begin{tabular}{lll}
\hline Parameter & Range & Typical \\
\hline Depth (m) & $0.7-0.9$ & 0.8 \\
Length (m) & $15-30$ & 23 \\
\hline
\end{tabular}

Assuming $l / w$ ratio of 10

$\Rightarrow l=10 w$, surface area of drying bed $A=l \times w=10 w^{2}$

$$
q_{e T}=l \times w \times w \times d
$$

Assume a depth of $0.8 m$

$$
q_{e T}=8 w^{2}, w=\sqrt{\frac{q_{e T}}{8}}
$$

Looking at the data generated from evaporation experiment, it shows that evaporation decreases with time as the quantity of water in the sludge decreases, and that the rate at which evaporation is taking place from the sludge is directly proportional to the instantaneous quantity of water present in sludge. It was shown that total loss of water due to evaporation from the sludge is given by the expression $q_{e T}=$ $w\left(T-\frac{e^{k T}}{k}\right)-q_{s} T-\frac{w}{k}$

This model can be used in the design of sludge drying bed using the design criteria shown in Table 4. The model is holistic having taken care of both evaporation and seepage losses in drying of sludge during calibration as shown in Tables 1 and 2 . 
A look at the materials balance shown in section 4.1, shows that at high seepage losses as a result of application of conditioner for drying, dewater ability enhancement ratios (DERs) would increase, and logically evaporation rate would reduce in accordance with this trend. Also pathogen die-off rate is a function of moisture content of sludge, long-term drying would favour microbial decay in consonance with Equation (5) developed by [14]. It is advisable always to enhance seepage losses in sand beds because of the faster rate of drying when compared to evaporation which is a very slow process and is often affected by climatic factors. To encourage filtrate generation, coarser sands are recommended because of larger pore spaces which induce percolation. A model developed by [13] to predict evaporation losses from sewage sludge drying bed suffers a major setback in that the model took care of sludge dewatered through evaporation only, while sludge dewatering is done through the processes of seepage and evaporation. It is expected that estimated rate of evaporation from sludge using this model will be higher since rate of evaporation is directly proportional to the instantaneous quantity of water in the sludge.

\section{CONCLUSIONS AND RECOMMENDATIONS}

Evaporation model shows that the rate at which evaporation is taking place from the sludge is directly proportional to the instantaneous quantity of water in the sludge and follows first order kinetic. The model will assist in the design of drying beds and the management of sewage sludge derived from various households' septic systems. Models to predict evaporation rate from sludge drying beds are scarce except the one of [13] and the one developed in this research to the best of our knowledge based on the literature available to us. Further research is recommended to improve on these models, because many factors affect evaporation that stochastic modeling would give the better result. Thermosystems should be built and used to concentrate solar radiation on the sludge surface to increase the rate of sludge drying.

\section{REFERENCES}

[1] Swanwick, J.D. et al., (1963). Advances in water pollution research. Vol. 2 Pergamon Press, 387.

[2] Agunwamba, J.C. (2001). Waste engineering and management tools. Immaculate Publications Ltd. Enugu
[3] Fulazzaky, M.A., Gany, A.H.A, (2009). Challenges of soil erosion and sludge management for sustainable development in Indonesia.Journal of Environmental Management 90, 2387-2392, Elsevier.

[4] Urbaniak, M. Hillebrand, B. (2004). Sludge drying and granulation for their future use, Mat.XVI conferencjiNaukowo-Technicznej nt. Aktualneproblemygospodarkiwodno-sciekowej, 27 - 28 wrzsniaUstron 2004, Wyd.Politechniki Czestochowa.

[5] Flaga, A. (2008). Sludge drying.Institute of Heat Engineering and Air Pollution, Cracow University of Technology, ul.Warszawska 24, 31 - 155 Krakow, Poland.

[6] Korczak-Niedzielska, M., Gromiec, M.J. (1998).Suszienieosadowsciekowych, Materialy VII Konf.Nauk-Techn.nt. Osadysciekowe w praktyce pod red. J.B. Bienna, Wydawnictwo PolitechnikiCzestochoskiej, Czestochowa.

[7] Bien, J.B. (2002). OsadySciekowe, Teoria I praktyka, WydawnictwoPoltechnikiCzestowoshoskiej, Czestochowa.

[8] Mesla, A. Buckler, G. Hanssen, B. (1999). Trocknung KommunalerKlarschlamme in Deutschland.Teil 2.korrespondenAbwasser 46(9): 1445 - 1456.

[9] Bux, M., Baumann, R. (2003a). Solare klarschlammtrocknung - Stand der Technic und Anwendungsbeispiele. In: Mull- Handbuch, Band 3, eds. D. Hosel, B. Biliteewski, W. Schenkel and H. Schnurer, 1- 13. Berlin: Erich Schmidt Verlag.

[10] Bux, M., Baumann, R., Philipp, W., Conrad, T., Muhlbauer, W. (2001). Class - A by solar drying. Recent experiences in Europe. In Proc. WEFTEC (Water Environment Federation) Congress, $14-18$ October, 2001. Atlanta Georgia.

[11] Bux, M., Baumann, R., Quadt, S., Pinnekamp, J., Muhlbauer, W. (2002).Volume reduction and biological stabilization of sludge in small sewage plants by solar drying. Drying Technology 20(4/5): $829-837$.

[12] Bux, M., Baumann, R. (2003b). Wirtshaftlichkeit und $\mathrm{CO}_{2}{ }^{-}$Bilanz der solarentrocknung von mechanischentwassertemklarschlamm. Abwasser 50(9): 1169-1177.

[13] Seginer, I., Bux, M. (2005). Prediction of evaporation rate in a solar dryer for sewage sludges. Agricultural Engineering International: The CIGRE journal. Manuscript EE 05 009. Vol. VII October, 2005.

Vol. 34 No. 4, October 2015 
[14] Obianyo, J. I., Agunwamba, J. C. (2015). Modeling of seepage losses in sewage sludge drying bed. Nigerian Journal of Technology. Vol. 34, No.1, January, 2015. Pp. 64 - 71.

[15] Obianyo, J. I., Agunwamba, J. C. (2015). Effect of conditioner on dewaterability of sewage. Nigerian Journal of Technology. Vol. 33, No.3, July, 2014. Pp. $618-625$.

[16] Obianyo, J. I. (2015). A study of faecal coliform dieoff in sewage sludge drying bed. Nigerian Journal of Technology. Vol. 34, No.3, July, 2015. Pp. 643 - 649.

[17] Cai, L., Gao, D., Chen, T.B., Liu, H.T., Zheng, G.D., Yang, Q.W. (2012). Moisture variation associated with water input and evaporation during sewage sludge bio-drying. Bioresour. Technol.117: 13-19.

[18] Cai, L., Chen, T.B., Gao, D., Zheng, G.D., Liu, H.T., Pan, T.H. (2013). Influence of forced air volume on water evaporation during sewage sludge bio-drying. Water Res. 2013 Sep.1; 47(13): 4767-73.

[19] British Standard 1377 (1975). Methods of test for soils for Civil Engineering purposes, British Standards Institution, British Standards House, 2 Park Street London.

[20] Carg, S.K., Carg, J. (2007). Hydrology and water resources engineering. Khanna Publishers Delhi, India 